University of Nebraska - Lincoln

DigitalCommons@University of Nebraska - Lincoln

Textile Society of America Symposium

Proceedings

Textile Society of America

$10-2020$

Tameji Ueno: A Living National Treasure of Kyoto Textiles

Keiko Okamoto

Follow this and additional works at: https://digitalcommons.unl.edu/tsaconf

Digitalrt of the Art and Materials Conservation Commons, Art Practice Commons, Fashion Design

Commens, Fiber, Textile, and Weaving Arts Commons, Fine Arts Commons, and the Museum Studies

detwerkns

Logo

This Article is brought to you for free and open access by the Textile Society of America at

DigitalCommons@University of Nebraska - Lincoln. It has been accepted for inclusion in Textile Society of America

Symposium Proceedings by an authorized administrator of DigitalCommons@University of Nebraska - Lincoln. 


\title{
Tameji Ueno: A Living National Treasure of Kyoto Textiles
}

\author{
Keiko Okamoto \\ Hosei University \\ okamoto9keiko@gmail.com
}

\begin{abstract}
Introduction
The Ministry of Education enacted the Act on Protection of Cultural Properties in order to preserve important cultural properties. Concurrently, they wanted to preserve skills of Japanese arts and crafts. In 1955, Tameji Ueno was one of the first five yüzen artisans appointed as an Important Intangible Cultural Property, known as a Living National Treasure. ${ }^{1}$ By that time, Tameji had been devoted to the research and establishment of Kyō-kaga yüzen style for almost 30 years. He died shortly thereafter, so only a few of his pieces are archived. However, Tameji's working style as an artisan reveals his endeavor to create merchandise as an art piece. In this paper, the author reviews Tameji Ueno and his family's 120 years of contribution to the manufacturing of hand-painted yüzen dyeing in Kyoto.
\end{abstract}

First, the structure of the Kyoto textile industry in the first quarter of the $20^{\text {th }}$ century is reviewed when Tameji's father worked as a high-end textile designer for hand-painted yüzen dyeing. Second, the process of hand-painted yuzzen dyeing, mainly adopted during the second quarter of the $20^{\text {th }}$ century, and the uniqueness of the Ueno studio compared to the general yūzen artisan's studios are explored. Then, Tameji's Kyō-Kaga features are examined in one of the privately owned pieces and the work of Tameji's successors are reviewed. Their high-end textiles for the kimono have been renowned in the industry, but close analysis reveals that their business was deeply affected by the Muromachi merchants in the Kyoto textile industry.

\section{Background}

The Meiji restoration (1868) negatively impacted on the Kyoto textile industry that had been the center of silk textile business for centuries. The abolishment of Buddhism and feudal domains, and the emperor's relocation to Tokyo reduced the consumption of silk textiles. ${ }^{2}$ However, with the support of Kyoto city and Muromachi merchants ${ }^{3}$ during the Japanese Industrial Revolution, the industry started recovering both in dyeing and weaving categories.

\footnotetext{
${ }^{1}$ Tameji Ueno, Katsuma Nakamura, Uzan Kimura, Kihachi Tabata, and Eiichi Yamada were the first five artisan yūzen dyers appointed as Living National Treasures. Yuzuru Okada and Katsuma Nakamura, ed. Ningen Kokuhō Series 12. (Tokyo: Kodansha, 1981).

${ }^{2}$ Tomoyuki Yamanobe, "Kyoto no Kindai Senshoku" [Modern Textiles in Kyoto], in Kyoto no Kindai Senshoku, eds. Muromachi Senshoku, Emaki Kaisai Iinkai, and Senshoku-ten Bukai (Kyoto: Kyoto Orimono Oroshi Shōgyō Kumiai, 1994), 9-16.

${ }^{3}$ Muromachi merchants were named after the Muromachi district in Kyoto where the textile business originally started in the mid-15th century. Adachi Masao, "Muromachi no Rekishi to Muromachi Shōnin [The History of Muromachi and Muromachi Merchants]," in Muromachi - Sono Seiritsu to Shinten [Muro-machi, The Establishment and Development], ed. Kyoto Orimono Oroshi Shōgyō Kumiai (Kyoto: Kyoto Orimono Oroshi Shōgyō Kumiai, 1979), 3-63.
}

Published in Hidden Stories/Human Lives: Proceedings of the Textile Society of America 17th Biennial Symposium, October 15-17, 2020. https://digitalcommons.unl.edu/tsaconf/ Copyright @ 2020 Keiko Okamoto doi: $10.32873 /$ unl.dc.tsasp.0104 
In the dyeing category, a mass-manufacturing method of multi-color motif dyeing was developed in 1881. ${ }^{4}$ It was called kata yūzen (pattern yūzen) that was developed using Japanese traditional kata-zome (pattern dyeing) method (paste resist) and imported chemical dye stuff from Western countries. Artisans and merchants wanted to replicate the textile designs of traditional laborintensive hand-painted $y \bar{u} z e n$ dyeing that was developed in the $17^{\text {th }}$ century. This new method made colorful motif dyed textiles available in multiple quantities. In the early $20^{\text {th }}$ century, silk screen print and roller print methods were introduced to Japan, which increased productivity at lower costs. The production quantity of yüzen dyeing as a whole increased by the $1930 \mathrm{~s}^{5}$ as more and more emerging middle-class consumers were willing to buy silk textiles that they were prohibited from wearing during the feudal era.

However, newer methods did not replace the hand-painted yüzen dyeing method completely because it could provide the quality that was desired for high-end silk kimono textiles. The Ueno family has been specializing in the high-end hand-painted $y \bar{u} z e n$ dyeing and providing sophisticated silk yuzzen textiles to the market all through the $20^{\text {th }}$ century to the present.

\section{The Father, Seikō Ueno}

At the end of the $19^{\text {th }}$ century, Seikō Ueno ${ }^{6}$ (18??-1943) was a textile designer and yüzen dyer. In those days, silk yüzen textiles were manufactured only for a limited number of upper-class Japanese. Seikō published many textile design books as shown in Figure 1. ${ }^{7}$ The majority of his textile designs found in these books are non-repeated motifs, indicating that the kimono was used as a formal wear. Most of the designs only show the main part of the kimono (i.e. lower body parts, etc.) but any yzuzen artisans could create other parts of the textile design (if needed) based on the common understanding of the kimono textile designs.

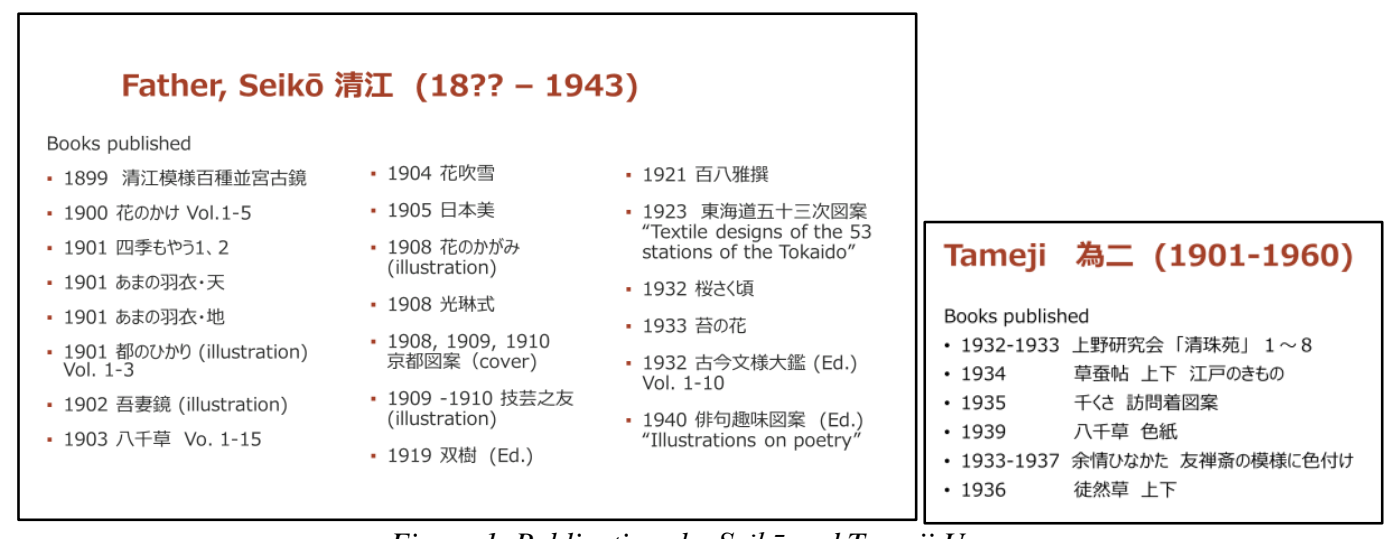

Figure 1. Publications by Seikō and Tameji Ueno

\footnotetext{
${ }^{4}$ Bunka Murakami, Kindai Yūzen-Shi [History of Modern Yūzen], (Kyoto: Unsōdō, 1927), 32-35. He estimates the original method was developed in 1876.

${ }^{5}$ Based on the statistics by Kyoto Chamber of Commerce and Industry, ed., Kyoto Shōko Kaigisho Tōkei Nenpō, Shōwa 12 - Shōwa 17 [Annual Reports of Kyoto Chamber of Commerce and Industry, Shōwa 12 - Shōwa 17] (Kyoto: Kyoto Chamber of Commerce and Industry, 1938), 96-97.

${ }^{6}$ His real given name was Jisaburo, 治三郎.

${ }^{7}$ Data collected from The National Diet Library. Some of the publications are illustrations on poetry.
} 
Agents and retailers used these books as textile design catalogs to take orders from consumers. Some of the imprints of the books carries addresses and names of distributors. ${ }^{8}$ When a consumer chose a textile design, the retailer forwarded the order to one of these agents together with a roll of white fabric (or fabric to be redyed). The agents then sent them to the Ueno studio. It could also be possible that the retailer forwarded the order to other agents or artisan dyers. When the ordered fabric was ready (dyed), it was sent back to the consumer via the agent and retailer. This style of business was called custom-made yüzen. ${ }^{9}$

During Seikō's time, the custom-made yūzen was common as a high-end formal wear. The number of Seikō's publications, however, declined as ready-made $y \bar{u} z e n^{10}$ prevailed in the market in the late 1920s.

\section{Kyoto Kimono Textile Industry \& Muromachi Merchants}

The main difference between the custom-made and the ready-made yüzen businesses is the distribution system. The dyeing methods and procedure are the same. Figure 2 shows the Kyoto kimono textile (silk yüzen \& dyed textiles) industry structure reported in 1940 by Kyoto Chamber of Commerce and Industry. ${ }^{11}$ Custom-made yüzen business flow (mentioned in the previous section) is shown in green, where a roll of textile goes back and forth during the business.

On the other hand, the fabric flow of the ready-made $y \bar{u} z e n$ business is unidirectional from merchants to consumers as shown in blue in Figure 2. In the ready-made yüzen business, Muromachi merchants played the main role. They purchased white fabrics and consigned them to $y \overline{u z e n}$ artisans and dyers. When the fabrics were dyed, merchants distributed them to retailers all around Japan. As more Muromachi merchants gained capital and developed a distribution network in the 1930s, the ready-made yüzen business became the mainstream in Kyoto textile industry. ${ }^{12}$

Textile designs, fabric constructions, and fiber types were the most important aspects of kimono fashion trends because the form of the kimono - T-shaped, straight-seamed, front-wrapped style - has almost been the same for some time. Hence, Muromachi merchants were eager to develop their shops' featuring innovative textile designs to be competitive in the industry. Especially, wealthy merchants spent a lot of money for developing high-end hand-painted yüzen dyeing for product differentiation. They collected old textiles from the feudal era for design ideas and employed a number of textile designers. New textiles were regularly showcased in their sales exhibitions aimed at sales agents, regional wholesalers, and retailers. ${ }^{13}$

\footnotetext{
${ }^{8}$ Seiko Ueno, Hana no Kake. vol. 2, 3, 4, 5. 1900. Seiko Ueno, Shiki Mayau. vol. 2. 1901.

${ }^{9}$ In Japanese, “Atsurae yūzen, 誂え友禅.

${ }^{10}$ In Japanese, Shire yūzen, 仕入れ友禅.

${ }^{11}$ Kyoto Chamber of Commerce and Industry and Ogata, Masato, ed. "Kyō Yūzen ni Kansuru Chōsa”, [A Survey on Kyō Yūzen], Kyoto: Kyoto Chamber of Commerce and Industry, 1940. 22.

${ }^{12}$ Based on the statistics by Kyoto Chamber ed., Kyoto Shōko Kaigisho Tōkei Nenpō, 96-97.

${ }^{13}$ Many of the exhibition catalogs are in the National Diet Library.
} 


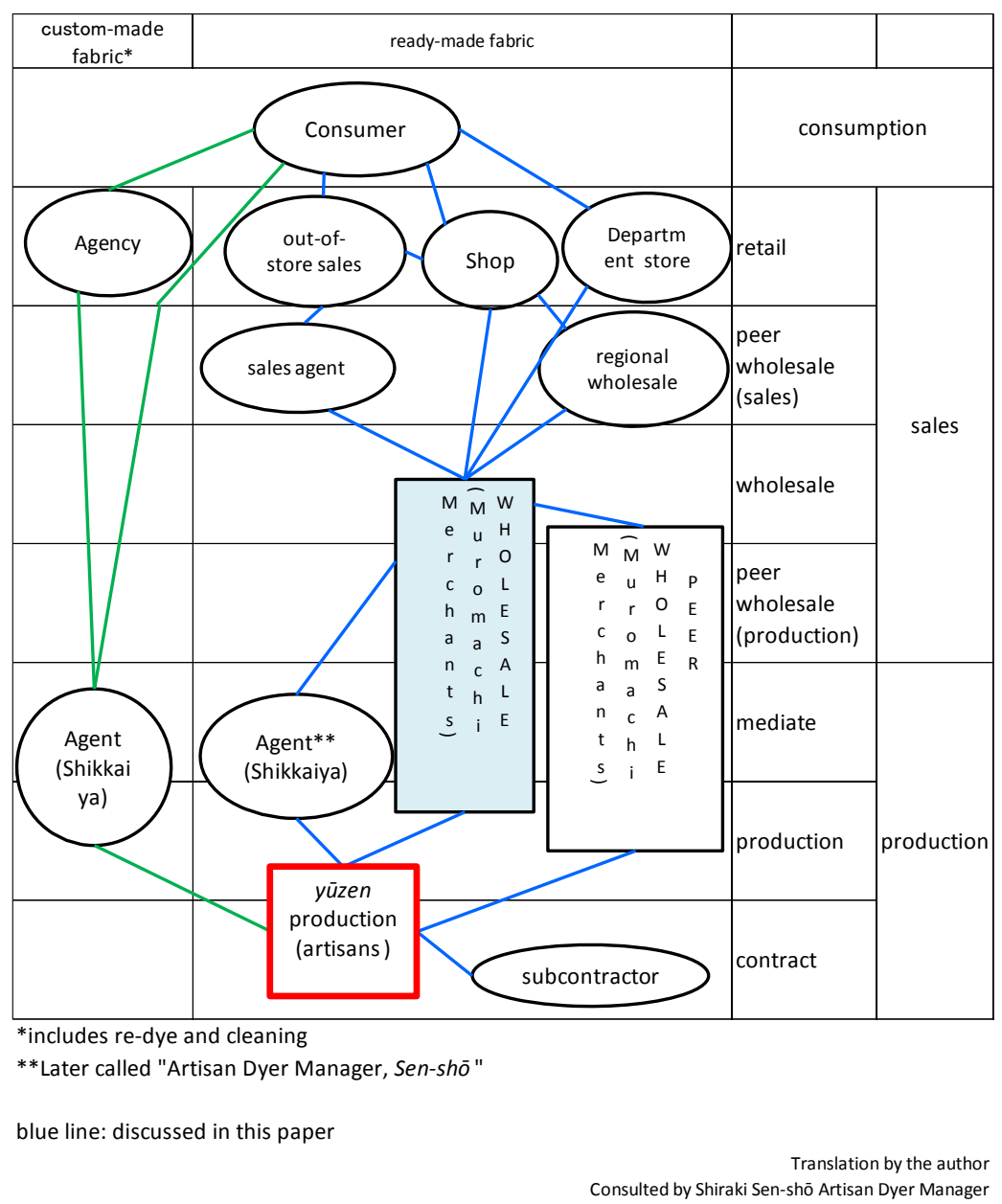

Figure 2. Structure of Kyoto kimono textile industry (silk yūzen and dyed textiles) (Kyoto Chamber of Commerce and Industry and Masao Ogata, ed.)

Ueno Studio (Research \& Development)

Tameji Ueno (1901-1960) joined his father Seikō's studio in 1925. Before joining the studio, Tameji studied at Kyoto Fine Arts School, ${ }^{14}$ learned Japanese paintings from Goun Nishimura, and then Western paintings at Kansai Academy of Arts. ${ }^{15}$

Father and son started collecting and researching old Kaga yüzen textiles from the feudal era. Kaga is the old name of the Ishikawa region where Kaga yuzzen was developed. Tameji learned old Kaga yüzen by replicating them. He then mixed the features of his researched old Kaga $y \bar{u} z e n$ and up-to-date Kyō yūzen trends and devised his original textile design style, the KyōKaga yüzen style. ${ }^{16}$ Kyoto Marubeni, one of the successful Muromachi merchants of the time, supported Ueno studio in this endeavor.

\footnotetext{
${ }^{14}$ In Japanese, “Kyoto-shi Bijutsu Gakko, 京都市美術学校”

15 In Japanese, “Kansai Bijutsuin, 関西美術院”

${ }^{16}$ Kenzo Fujii, "Kyō Yūzen Zome to Kaga Yūzen Zome [Kyō Yūzen Dyeing and Kaga Yūzen Dyeing], in Yūzen Monogatari: Kyō Kaga no Bi (Kyoto: Unsodo, 2007), 80-83.
} 
Seikō and Tameji became the member of Kyoto Marubeni's sales exhibitions, Biten. Biten is the abbreviation of Senshoku Bijutsu Tenrankai, meaning Textile Art Exhibition, but it actually was a wholesale exhibition. The exhibition started in 1927 and continues to this day except for the war period. In each exhibition, they published a catalog. Three of Seikō's pieces were awarded in 1932 exhibition. One of them, the item number 7, depicted a scenary of Kaga yüzen style. ${ }^{17}$ Several of Tameji's pieces are also witnessed in the catalogs. ${ }^{18}$ But none of the artisans' names were printed next to the textiles. This may indicate that names of renowned artisans were not used as marketing tools to influence retailers or consumers.

Tameji also published several textile design books based on his research as shown in Figure 1. In "Yojō Hiinakata," which has the same title as the one by Yuzensai Miyazaki, the developer of $y \bar{u} z e n$ dyeing method in the $16^{\text {th }}$ century, Tameji modified and colored the original textile designs. ${ }^{19}$ Tameji's textile designs published between 1932 and 1937 were all black and white woodblock print, such as in "Chikusa," "Yojō Hiinakata," "Tsurezuregusa," and "Seijuen," 20 but Unsodo, the main publisher of his books, published some of the colored reprints in $2007 .{ }^{21}$

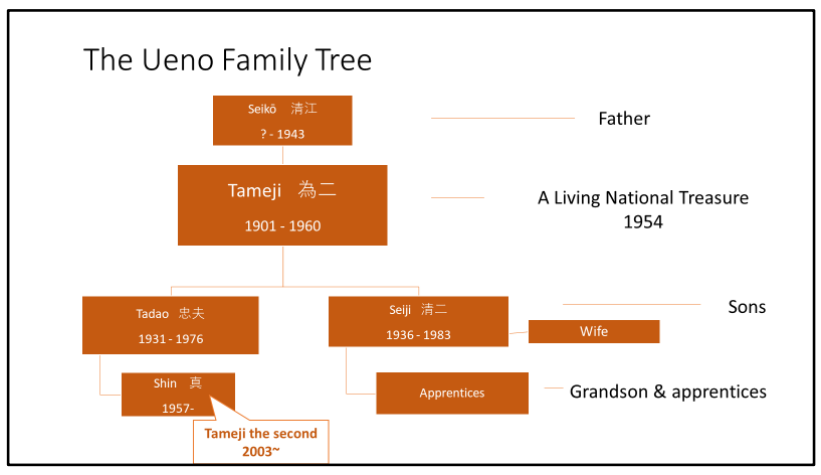

Figure 3. The Ueno Family Tree

According to the Ueno family tree shown in Figure 3, the work years of Tameji and his father overlap almost 18 years. However, the last few years must have been a hard time for them to work under the Sumptuary Law and clothing ticket system because of the Pacific War. Tameji's two sons joined the studio after they graduated from college in the latter half of the $20^{\text {th }}$ century.

\section{Uniqueness of the Ueno Studio (Processes of Hand-Painted Yūzen Dyeing)}

\footnotetext{
${ }^{17}$ Kabushikigaisha Marubeni Shōten Kyoto Shiten, ed., Dai Jukkai Senshoku Bijutsu Tenrankai [10th Textile Art Exhibition Catalog] (Kyoto: Unsodo, 1932), item 7.

${ }^{18}$ Maubeni Shōten Kyoto Shiten, ed., Dai Nijukkai Senshoku Bijutsu Tenrankai [20th Textile Art Exhibition Catalog] (Kyoto: Unsodo, 1936), item 31. One exhibited in the $13^{\text {th }}$ Textile Art Exhibition. Colored photos in Ruiko Kato. 13 in "Tashikana Waza ni Kaoru Hanayagi" [Beautiful Techniques]." In Shükan Ningen Kokuhō 61 Kogei Gijutsu Senshoku 12 Yūzen: Sandai Tabata Kihachi, Kimura Uzan, Ueno Tameji, Hata Tokio, 10-14. (Tokyo: Asahi Shinbunsha. 2007).

${ }^{19} \mathrm{He}$ wrote about this in the pre-face of the book.

20 Tameji Ueno, Chikusa. (Kyoto: Unsodo, 1935). Tameji Ueno, Yojō Hiinakata. (Kyoto: Unsodo, 1933-1937).

Tameji Ueno, Tsurezuregusa. (Kyoto: Unsodo, 1936). Ueno Kenkyukai, Seijuen, (Kyoto: Unsodo, 1932-1933).

${ }^{21}$ Ueno Tameji, Yūzen Monogatari: [A Yūzen Story: The Beauty of Kyō-Kaga Yūzen]. (Kyoto: Unsodo, 2007).
} 
There are two types of $y \bar{u} z e n$ artisan workshops in the red square in Figure 2. One is a factory where kata $y \bar{u} z e n$ and/or other newly introduced mass-production methods were processed. The factory primarily handles dyeing steps from the beginning to the end. The other is a group of independent artisan studios where each studio is in charge of one step of the hand-painted yüzen dyeing process.

Generally, in hand-painted yūzen dyeing studios in Kyoto, one artisan studio specialized only in one step of the dyeing process because they were considered as an expert of a certain step in the dyeing process. It is an effective way to obtain high-skilled artisanal work, observable from the long history of textile dyeing in Kyoto. For example, a textile designer only painted textile designs on a piece of paper, a draft drawer drew draft on white fabrics with washable indigo, an outline drawer drew outlines with paste resist using a rice paper squeezer with metallic nozzle, and a $y \bar{u} z e n$ dyer colors outlined motifs. As a result, there were about 20 artisan studios involved in manufacturing a bolt of fabric as shown in Figure $4 .^{22}$

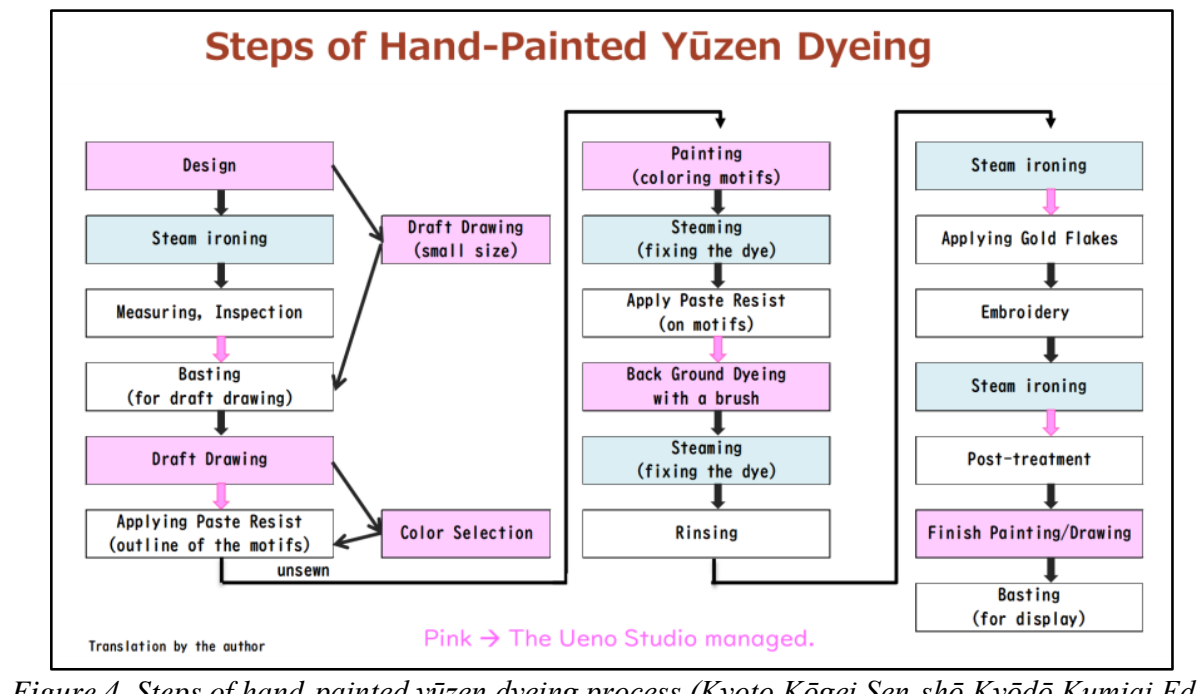

Figure 4. Steps of hand-painted yūzen dyeing process (Kyoto Kōgei Sen-shō Kyōdō Kumiai Ed.)

A typical master artisan dyer ran a studio that was comprised of a few to several dozen junior artisans and apprentices, all specializing in the same skills as the master. In order to organize each artisan studio, an agent (shikkaiya) ${ }^{23}$ in Figure 2 arranged the sequence of work. The agent did not process any dyeing steps, but he first discussed the final image of the kimono with the Muromachi merchant who was the owner of the white fabric. The agent brought the fabric to the first artisan studio and instruct the final image of the textile, then to the next artisan, and so on. One studio applied only one step, and the time they took depended on the workload. This may

\footnotetext{
${ }^{22}$ Based on the diagram in Kyoto Kōgei Sen-shō Kyōdō Kumiai, ed, "Kyō Tegaki Yūzen, Senshō - Dentō no Waza, Kyō no Kimono" [Kyoto Hand-painted Yūzen, Senshō Traditional Techniques, Kyoto Kimono] (Kyoto: Kyoto Kōgei Sen-shō Kyōdō Kumiai, n.d.).

${ }^{23}$ In recent years, shikkaiya is called senshō, an Artisan Dyer Manager.
} 
be one of the reasons why the names of the artisan dyers were anonymous. Instead, some of the agent names ${ }^{24}$ were seen as awardees in Biten exhibition catalogs.

The uniqueness of the Ueno studio was that they worked directly with Muromachi merchants and processed multiple steps in their own studio as shown in pink in Figure 4. They not only processed textile designs but also draft drawings, coloring motifs, color selections, and final drawings. They also played the role of an agent, shikkaiya to coordinate affiliated artisans who processed steps such as applying outline paste resist and background dyeing. But regardless of whether they or the affiliated artisans processed the steps, the studio was responsible for the final textiles. Tameji was a studio owner and artisan, at the same time, he played the role of an agent.

By working directly with merchants and affiliated artisan studios, Tameji gained a sense of design to fulfill the merchants' requirement, such as the final image of the textile, the costs, and so on, which must have been recognized when he was appointed as National Treasure. However, in daily business, artisans worked based on commissions so that they had to follow instructions of the Muromachi merchants, such as the expected final image of the textiles, age range of their target consumers, color image, density of motifs, degree of formality, and budget. Hence, Tameji did not have the freedom to dye as he wanted. On the other hand, Tameji and fellow artisans had plenty of opportunities to hone their artisanal skills with provided white fabrics.

\section{National Treasure, Tameji Ueno}

In 1943, when the Sumptuary Law limited the manufacturing of luxury textiles, Tamej was appointed as one of the skillful artisans who could continue manufacturing high-quality yüzen textiles for the purpose of preserving the skills. This gave him access to scarce materials during war. After the war, the Ministry of Education appointed him as an Important Intangible Cultural Property of Kyō yūzen in 1950 and then of yüzen dyeing after the 1954 Reformed Act. ${ }^{25}$

Tameji's had his own reasons in becoming an Important Intangible Cultural Property. He believed that the high skills of hand-painted yüzen dyeing should be handed down to the next generation at a time when Western culture was rapidly replacing traditional cultures, and massproduced products flooded the market in the post-World War period. Tameji, more importantly, wanted his kimono textiles to be admired as wearable art with his signature on them and to be directly promoted to consumers, not via the distribution network of the powerful Muromachi merchants. He wanted to improve the artisans' status in the industry. ${ }^{26}$

Tameji and his fellow artisans established a guild ${ }^{27}$ to preserve their skills and exhibit their textiles directly to consumers. They held the first Japan Traditional Kogei (Art \& Crafts)

\footnotetext{
${ }^{24}$ Shin’ichiro Atsumi 渥美新一郎, Bunjiro Ikegaki 池垣文次郎, and Genbei Sawatari 澤渡源兵衛. Marubeni. Kabushikigaisha Senshoku Bijutu Kenkyukai, ed. Biten: Shōwa no Ayumi [Biten: Showa History]. 9. (Kyoto: Kyoto Marubeni Kabushikigaisha Senshoku Bijutu Kenkyūkai, 1989).

${ }^{25}$ Riyo Kikuchi, “Mukei Bunka Isan Toshite no Kōgei Gijutsu: Senshoku Bun'ya wo Chūshin Toshite [Craft Techniques as Intangible Cultural Heritage: with Empasis on Textiles]," Research and Reports on Intangible Cultural Heritage, no.3 (2009).

${ }^{26}$ Kazuko Todate. Nakamura Katsuma to Tōkyō Yūzen no Keifu, [Nakamura Katsuma and Tokyo Yūzen: The Development of the Individual Yūzen Artist]. (Kyoto: Senshoku to Seikatsusha, 2007.) 104-125.

${ }^{27}$ Katsuma Nakamura and Uzan Kimura. Nihon Kōjin-sha (1953), Nihon Kōgei-kai (1955).
} 
exhibition in 1954 and worked closely with the Ministry of Education for the appointment of Living National Treasures. ${ }^{28}$

\section{Tameji's Archives}

"Kanki" ${ }^{29}$ preserved at the Tokyo National Museum is a well-known Tameji's piece that he manufactured as an archive after the appointment of a Living National Treasure. Prior to this, on November 10, 1953, he submitted a roll of fabric to the Ministry of Education for the screening process. At the end of the roll was a message written by Tameji asking that the piece be considered as an Intangible Cultural Property; it was then dedicated to one of the patrons, a Muromachi merchant, Mr. Tsutomu Tsugita on December 14, 1953. The fabric is now mounted on a screen as shown in Figure 5. In this section, details of this textile are reviewed.

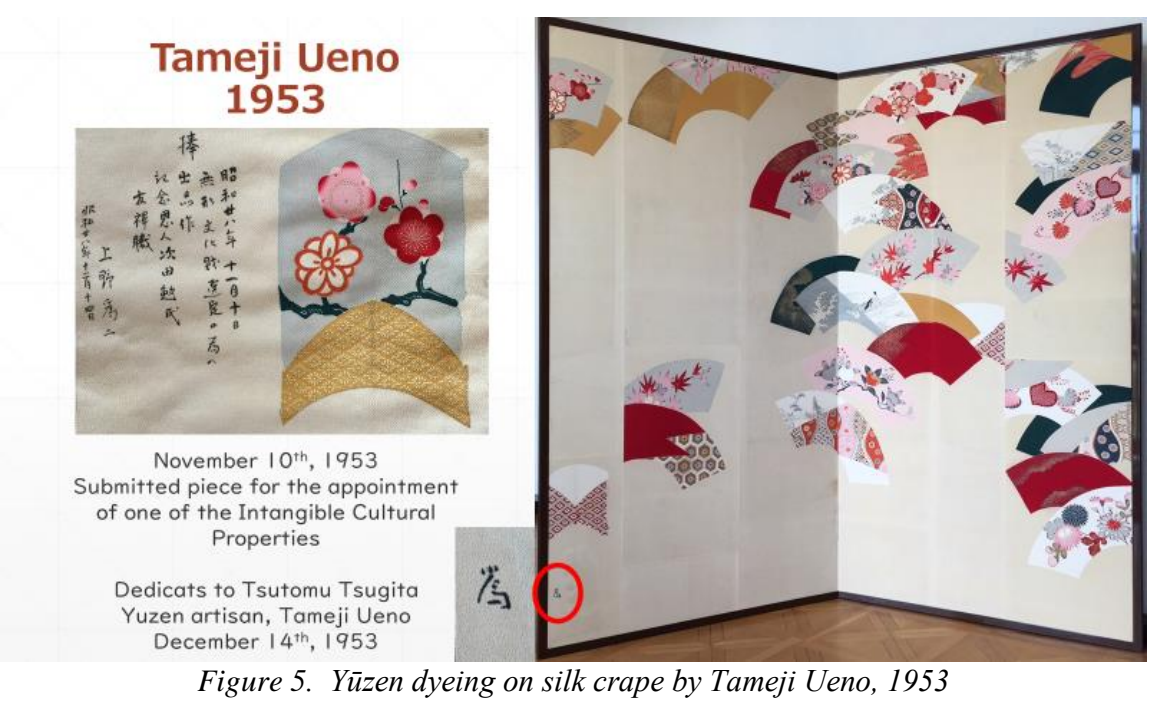

This piece was originally made for a kimono jacket. The textile design is a layout of Japanese folding fans, sensu. Each shape illustrates the paper part of the fan. The area within each shape is hand-painted motifs dyed using a combination of various yūzen methods and skills. It has his signature on the left bottom corner. Tameji shows a variety of $y \bar{u} z e n$ skills in this piece, which is

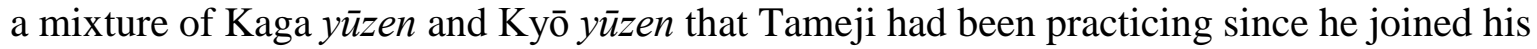
father's studio. The colors used in this piece reveal that the textile has Kaga yüzen taste, while the structure of the textile design reminds of Kyō yūzen.

Figures 6 to 10 detail the silk piece shown in Figure 5. One of the remarkable features of Kaga $y \bar{u} z e n$ is seen in bug-bitten coloring. It is called mushikui (bug bites) in Japanese. When a small insect crawls on a leaf or bites fruits, its color or shape changes. Mushikui (bug-bitten) coloring techniques show that effect. Figure 6 shows different types of bug-bitten coloring on chrysanthemum leaves, maple leaves, bamboo grasses, and citrus tachibana.

Figure 7 depicts chrysanthemum flowers and leaves, each of which uses different method. One leaf is bug-bitten, and the other leaf has gold gritter veins. One of the chrysanthemums is

\footnotetext{
28 Todate. Nakamura Katsuma. 104-125.

${ }^{29}$ Tameji Ueno, Kanki, 1955. https://webarchives.tnm.jp/imgsearch/show/C0089692
} 
embroidered and the petals of another are colored with gradation having darker colors on the edges. Kaga yüzen usually prefers darker colors on the edges, while Kyō-yūzen flowers usually have darker colors on the central parts.

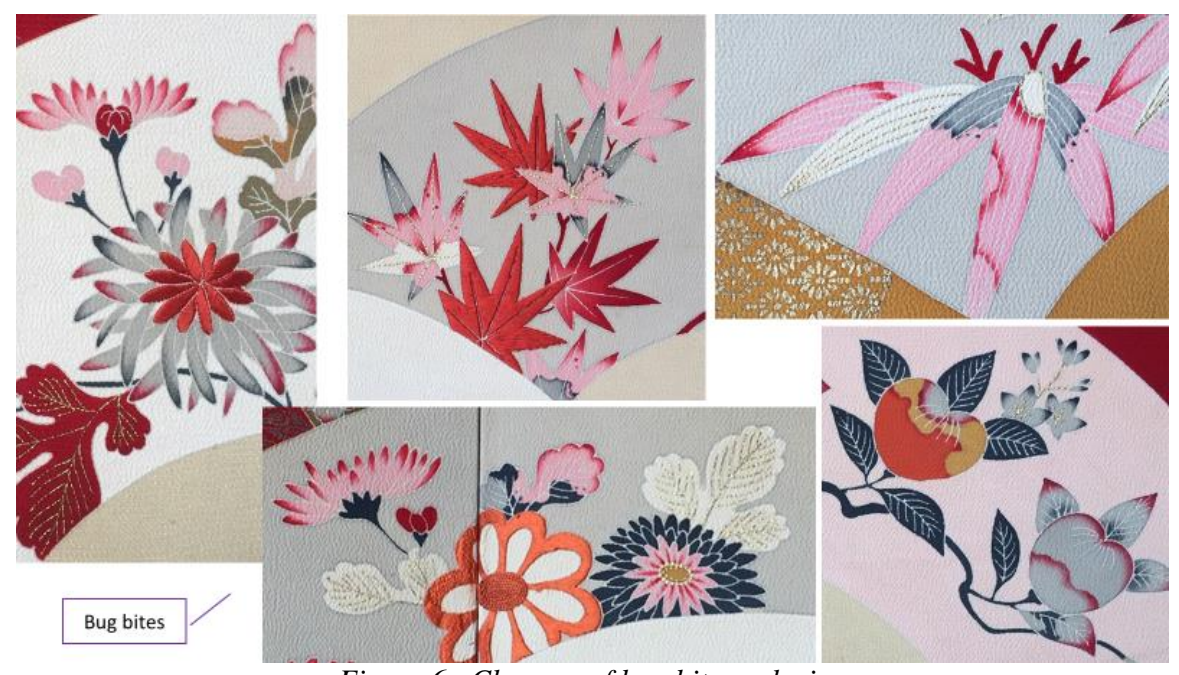

Figure 6. Close up of bug bites coloring

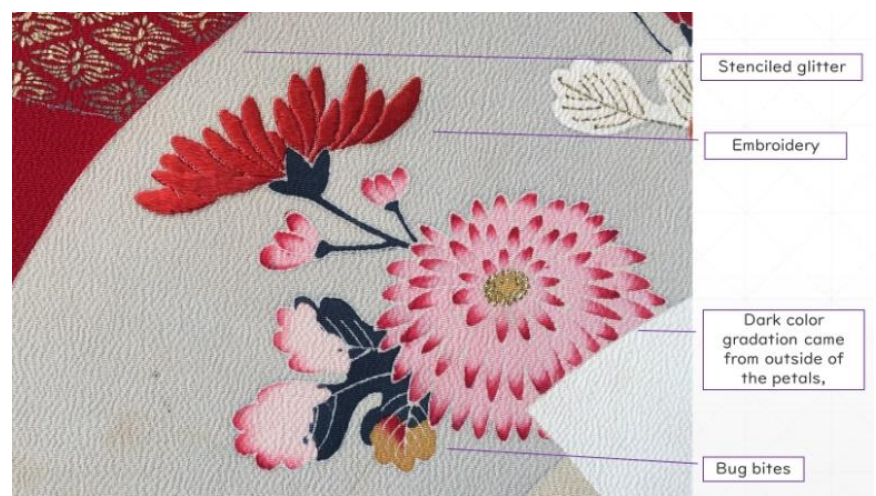

Figure 7. Close up of bug bites and petal gradation

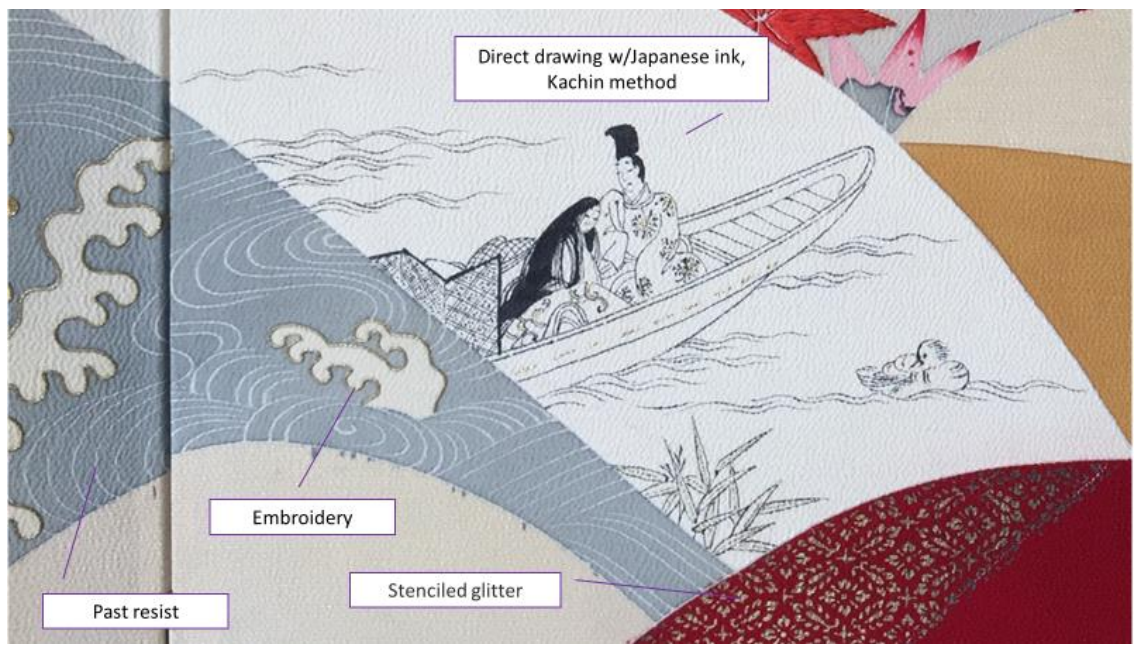

Figure 8. Kachin, paste resist, embroidery, and stenciled glitter 
In Figure 8, thin black lines were used to depict a couple on a boat. The lines were drawn in free hand using Japanese ink. It is called kachin method. Waves in gray color also uses hand-painted $y \bar{u} z e n$ method and the outlines of the crest were embroidered with gold thread.

In Figure 9, plum flowers on the upper corner are depicted using solid color yūzen, embroidery, and gradation that have darker color on the edges. Stenciled glitter on red background depicts two cranes in a rhombus shape. Multiple-color geometric patterns are all hand-painted yüzen dyeing. Geometric designs are seen more in Kyō yūzen. Tameji used embroidery on quite a few motifs. Kaga yūzen uses subtle colors, while Kyō yūzen prefers gold and bright colors for embroidery. Gold leaves, gold flakes, and glitter are more seen in Kyō yūzen.
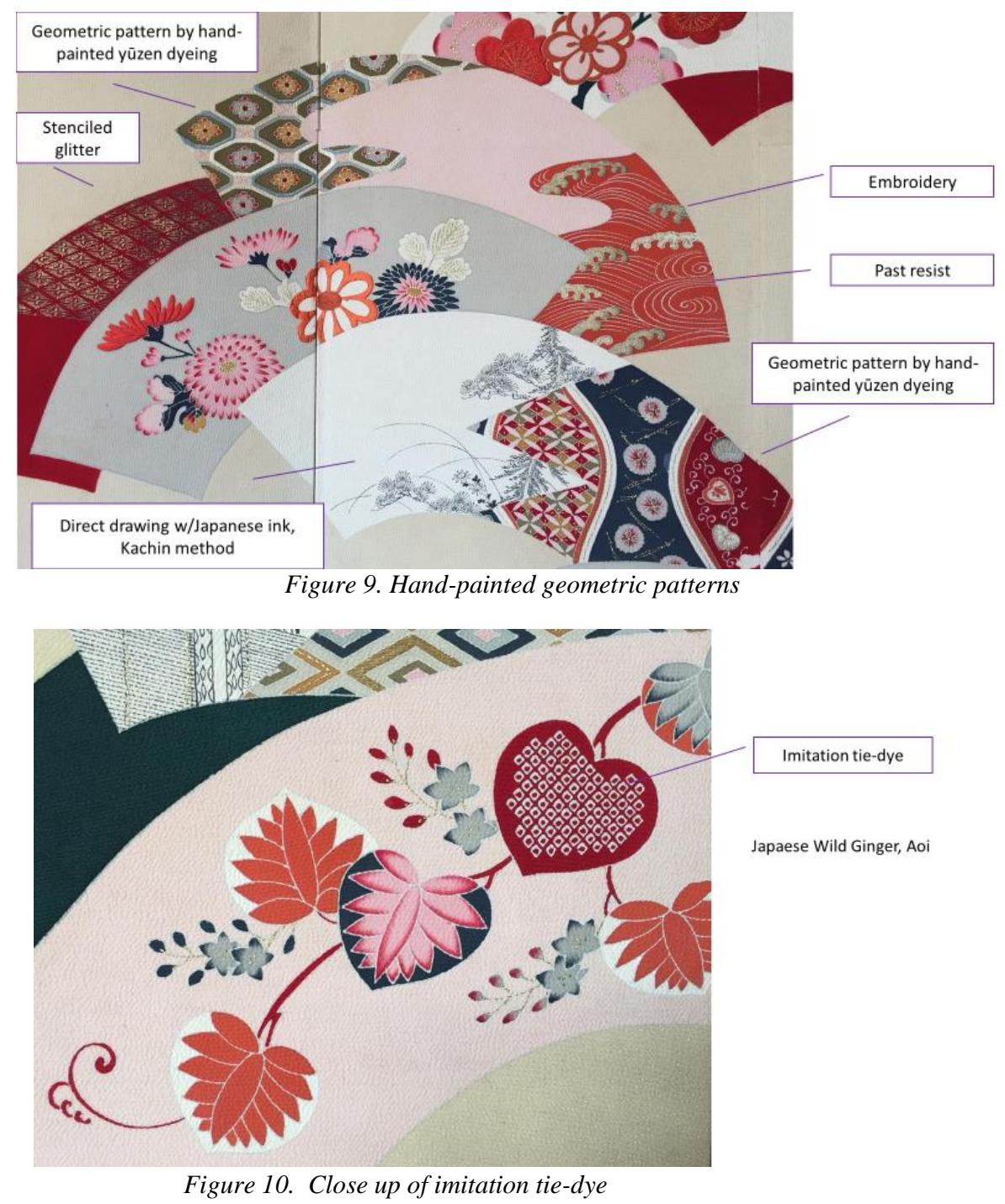

In Figure 10, a variety of Japanese Wild Ginger, aoi, is placed. The red aoi leaf in the center is decorated with imitation tie-dye. The imitation tie-dye is usually depicted using a pattern and is often seen in Kyō yūzen, but here Tameji uses hand-painted imitation tie-dye. 
To summarize, in this Tameji textile, Kaga yz̄zen tastes are seen in Kaga basic colors, ${ }^{30}$ bug bites, and shading directions in a motif, while Kyō-yūzen tastes are seen in the layout of the fans, mixture of flowers and geometric motifs, imitation tie-dye, and kachin. Although there is no clear definition to distinguish the two yüzen textile designs, the basic textile design of Kaga $y \bar{u} z e n$ is like a sketch of a landscape, while that of Kyō yzuzen was more design oriented. Tameji

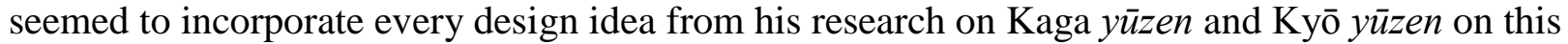
piece and use every skill he obtained.

Apart from these traditional motifs discussed above, Tameji worked on modern textile designs. One of them was a long flowing sleeve kimono that conveyed foreign motifs, peacock, and sarasa (chinz) set in a traditional kimono textile design. ${ }^{31}$ His last piece, "Yorokobi" 32 exhibited in the $3^{\text {rd }}$ Japan Traditional Art Crafts (Kogei) Exhibition in 1960, was an abstract design. Critics said that his design might have changed if he had lived longer. Unfortunately, Tameji passed away in 1960 at the age of 59.

After all, the Living National Treasure system did not change the kimono business model or the relationship between Muromachi merchants and artisans. There were no other efficient ways available for artisans and their merchandise to reach consumers throughout Japan without the Muromachi merchants' capital and distribution network.

\section{Two Sons and Their Successors}

After Tameji passed away, his two sons split the studio and each studio independently did business with Muromachi merchants. Both the studios succeeded Kyō-Kaga textile design features that their grandfather and father established. Their features were highly recognized and desired by the newly emerging upper-class consumers during the Japanese economic growth period.

When yüzen production as a whole started declining in the $1970 \mathrm{~s},{ }^{33}$ Muromachi merchants categorized the high-end hand-painted yüzen dyeing as "tokusen (luxurious selections)" and marketed it to retailers and consumers. Both of the Ueno studios gained a status as they provided merchandise to tokusen. By this time, signatures became commonly used by hand-painted yüzen artisans who process original textile designs and did the coloring like the Ueno family. It was probably because Muromachi merchants learned that names of the Western clothing designers were attracting consumers in the Japanese market. The son's studios performed well into the mid-1990s.

Tameji's features are seen in modified textile designs by his sons' studios. For example, Juzan no Akebono (Dawn at Mr. Juzan), ${ }^{34}$ manufactured by Tameji in 1958 depicts a scenery of hills and

\footnotetext{
${ }^{30}$ Dark red, ocher, green, indigo, and black (dark purple)

${ }^{31}$ Kato, "Tashikana Waza." 14.

${ }^{32}$ Nihon Kogeikai Ed. Nihon Dentō Kogeiten Zuroku, Dai san kai. 1956. Page unknown. Colored photo is in Kato Ruiko. 14 in "Tashikana Waza."

${ }^{33}$ Figures in Keiko Okamoto, "The Modern Development of Kyoto Textiles for the Kimono", in The Social Fabric: Deep Local to Pan Global; Proceedings of the Textile Society of America 16th Biennial Symposium (Vancouver: Textile Society of America, 2018), n.p., https://doi.org/10.32873/unl.dc.tsasp.0042

34 Tameji Ueno, Juzan no akebono. 寿山の曙 https://search.artmuseums.go.jp/records.php?sakuhin=10714
} 
islands covered with pine trees in a hazy background. His sons reproduced it by modifying the density and colors of the pine trees based on target consumers' age range and retail price. Ōmi Hakkei $^{35}$ (Eight Views of Ōmi), another Tameji piece, manufactured in 1933, has been a popular textile design of the sons' studios. Over the years, each of the Ōmi eight views were designed in a season.

Tameji's older son, Tadao (1931-1967), passed away before his son (Tameji's grandson, Shin, 1957- ) joined the studio in 1983. In 2003, the son succeeded as Tameji the second. He now works with an old artisan from his father's era.

Tameji's younger son, Seiji (1936-1983) established the Ueno Design Studio and created the house name of "Seisenkyo." 36 He put the house name as a signature, together with his own, on the textiles manufactured in the studio because he hoped that the studio could last forever. But it is assumed that he only put his signature on his original pieces. For example, he created his original pieces inspired by the trip to India in 1978.

In those days, instead of collecting old textiles for artisan's design resources, merchants offered an overseas research trip. One of the Muromachi merchants, Tsugita K.K., arranged a tour to India for Seiji to explore Indian textiles. Textiles he created, which were definitely not KyōKaga yuzzen, were showcased in "Textile Trip to India, Cinz \& Kimono" during one of the merchant's monthly exhibitions. ${ }^{37}$ It is of great interest as to how Seiji designed Indian cinz into his pieces, details are unknown except for a couple of small black and white exhibition photos.

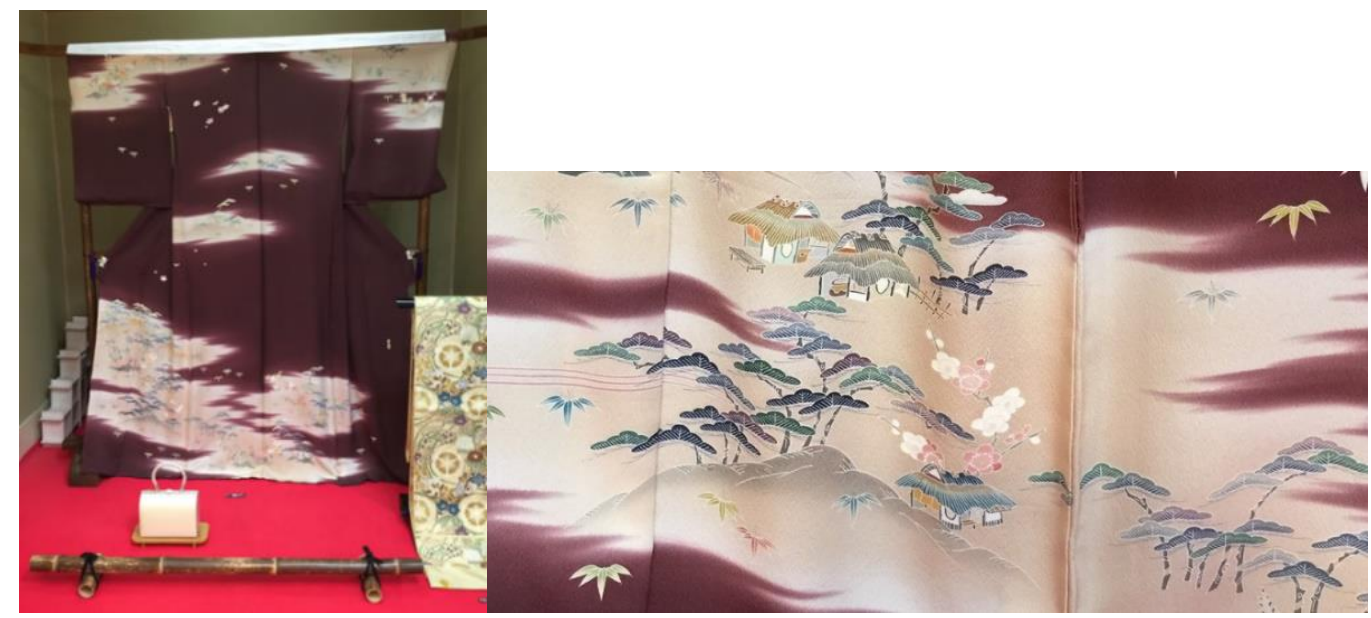

Figure 11. Recent merchandise by Ueno Design Studio, Seisenkyo (清染居), left

Figure 12. A close up of Figure 11, right

The younger son also died at the young age of 46 . The business and the house name were taken over by his wife, and apprentices and affiliated artisans kept manufacturing Kyō-Kaga yūzen textiles under the house name. They modified and reproduced Tameji and his younger-son's

\footnotetext{
${ }^{35}$ Exhibited in the 13th Textile Art Exhibition. Colored photo in Kato Ruiko. 13 in "Tashikana Waza."

${ }^{36}$ In Japanese, 清染居.

${ }^{37}$ Ueno Seiji, Indo Senshoku no Tabi, Tsugita [Ueno Seiji, Textile Trip to India, Tsugita]. In Some to Ori, May. 121, 1978.
} 
textile designs. The last apprentice who is now an independent artisan still manufactures merchandise for the studio. Unfortunately, none of the four children of the younger son adopted the artisanal vocation and therefore, even though the house name survives; there will be no one who can process the Ueno family's traditional skills of hand-painted yzuzen dyeing in the near future.

Textiles that apprentices of the younger son manufactured in the late 1980s were often published in the Beautiful Kimono magazine (Utsukushii Kimono) ${ }^{38}$ sponsored by merchants. These textile designs and colors remind us of Tameji's features. Figure 11 is a recent kimono manufactured by the younger son's studio, and Figure 12 is its close-up. It is a scenery of traditional country houses surrounded by natural plants, such as pine trees, bamboo leaves, plum flowers, chrysanthemums, maples, cedar, and hagi (bush clovers). The textile design has not undergone much change since the 1980s. However, the colors are more saturated, in other words, more Westernized. This piece was displayed at the shopping arcade in the Imperial Hotel Tokyo in 2019. ${ }^{39}$

\section{Discussion}

There has never been a time when so many Japanese consumers enjoyed silk kimono other than in the $20^{\text {th }}$ century. Japanese women, especially, enjoyed silk yüzen textiles. Most of them were mass-manufactured textiles, but among them were some hand-painted yüzen textiles that skillful artisans manufactured. The four generations of the Ueno family contributed to providing this high-end hand-painted yuzzen dyeing. Their business was only a part of the industry activity, but by looking at their history along with their textiles, the trend of the Muromachi merchants' business was reflected on it.

When Tameji's father worked as a textile designer, hand-painted yūzen dyeing was meant for a limited number of upper-class Japanese, meaning that the merchants' business was still under development. Tameji and his father brought about various innovative textile designs when the market was expanding in the 1930s. Merchants spent money on research and development to support artisans. It is unfortunate that not many archives are left in the industry.

In those days, it was rare for artisans to put their signatures on the textiles. Even merchants' exhibition catalogs did not carry artisans' names. It was probably because manufacturing was done by a group of artisans, and consumers were more interested in textile designs rather than designer names. In the Muromachi merchants' business, artistic pieces and mass-merchandise were not distinguished, but were treated as merchandise in different prices for different classes of consumers.

Even after World War II, the only chances for Tameji to create wearable art as merchandise were for exhibitions by the guilds that he and his fellow artisans established, such as Japan Traditional Kogei Exhibitions. However, the scale of the business was incomparable to that of the merchants.

\footnotetext{
${ }^{38}$ Utsukushii Kimono [Beautiful Kimono], 1987, Vol. 142, p. 87, 94, 99, 104. Ibid. 1989, Vol. 150, p. $309,104$. Ibid. 2004. Vol. 210, cover, p.4.

${ }^{39}$ The retail price of this textile was about USD12,000. This price does not directly reflect the cost of the product.
} 
After Tameji's two sons succeeded the business, the environment in the industry started changing. As presented in the TSA2018 symposium, ${ }^{40}$ daily silk casual wear production/sales started declining and the merchants' business shifted to formal and ceremonial wear of silk yüzen textiles. Merchants kept supporting artisans to develop new textile designs and encouraged them to put their signatures on the merchandise.

Consumers preferences also started changing to less innovative and more traditional textile designs, which was favorable for the Ueno studio that had plenty of the family's traditional textile design drafts along with the recognized status of the family.

Further market shrink brought the studios no option other than downsizing. In that situation, it was hard for apprentices to improve their yüzen dyeing skills. Moreover, it was hard for them to see their future in the industry. Consequently, apprentices left the studios one by one. The downturn that the Ueno family experienced in the fourth quarter of the $20^{\text {th }}$ century and beyond was the same as what the Muromachi merchants' business experienced in Kyoto.

\section{Conclusion}

The artisans from the Ueno family, Seikō, Tameji, his two sons, and their successors had worked closely with Muromachi merchants. The family passed down the Kyō-Kaga style of handpainted $y \bar{u} z e n$ textile designs and its skills for generations, which kept the studio status high in the industry. However, textile designs that were once recognized as innovative designs became to be considered somewhat traditional as the merchants' business narrowed down to yüzen textiles, and then started shrinking.

It is assumed that quite a few textiles were manufactured by the Ueno family, but because of the characteristics of hand-painted $y \bar{u} z e n$ dyeing, it was not possible to archive textile samples once a single piece was manufactured and sold. The same as other materials manufactured by other skillful artisans. At the TSA2018 symposium, the author proposed to locate and preserve textiles that were manufactured in the 1950s and 1960s. This time again, the author would like to propose that artistic textiles manufactured by artisans, such as the Ueno family in the early days, be discovered and preserved.

In this research, only one family and their featured textiles are reviewed in order to learn their contribution to the industry. In future research, it is proposed to focus on Muromachi merchants and merchandising strategy in the Kyoto textile industry.

\footnotetext{
*Acknowledgment

I would like to express my special thanks to Mr. Honda, the President of Sen'i Shinpo-sha, for introducing me to Mr. Shin Ueno, a grandson of Tameji Ueno. I would like to thank Machiko Ueno, the present Seisenkyo brand owner for giving me a chance to work in the studio and learning hand-painted yüzen dyeing in the 1980s; Koichiro Hara, ex-apprentice head, for sharing stories about the studio after 1990; and Nobuko Okamoto for preserving Tameji's piece on a screen. I would also like to thank Kodaimaru store for letting me to take pictures of their merchandise, Seisenkyo kimono textile.
}

Bibliography

Adachi, Masao. "Muromachi no Rekishi to Muromachi Shōnin [The History of Muromachi and

\footnotetext{
${ }^{40}$ Okamoto, “The Modern”, n.p.
} 
Muromachi Merchants]". In Muromachi - Sono Seiritsu to Shinten, [Muro-machi, The

Establishment and Development], edited by Kyoto Orimono Oroshi Shōgyō Kumiai, 3-63. Kyoto: Kyoto Orimono Oroshi Shogyo Kumiai, 1979.

Fujii, Kenzo. "Kyō Yūzen Zome to Kaga Yūzen Zome" [Kyō Yūzen Dyeing and Kaga Yūzen Dyeing]. In Yüzen Monogatari: Kyō Yüzen no Bi, 80-83. Kyoto: Unsodo, 2007.

Kato, Ruiko. "Tashikana Waza ni Kaoru Hanayagi” [Beautiful Techniques]. In Shukan Ningen Kokuho 61 Kogei Gijutsu Senshoku 12 Yüzen: Sandai Tabata Kihachi, Kimura Uzan, Ueno Tameji, Hata Tokio, 10-14. Tokyo: Asahi Shinbunsha. 2007.

Kabushikigaisha Marubeni Shōten Kyoto Shiten ed. Dai Jukkai Senshoku Bijutsu Tenrankai [10th Textile Art Exhibition Catalog]. Kyoto: Unsodo, 1932.

Kikuchi, Riyo. "Mukei Bunka Isan Toshite no Kōgei Gijutsu: Senshoku Bun'ya wo Chūshin Toshite" [Craft Techniques as Intangible Cultural Heritage: with Empahisis on Textiles]. Research and Reports on Intangible Cultural Heritage, no. 3 (2009). 37-59.

Kyoto Chamber of Commerce and Industry, ed. Kyoto Shōko Kaigisho Tōkei Nenpō, Shōwa 12 - Shōwa 17 [Annual Reports of Kyoto Chamber of Commerce and Industry, Shōwa 12 - Shōwa 17]. Kyoto: Kyoto Chamber of Commerce and Industry, 1938. 96-97.

Kyoto Chamber of Commerce and Industry and Ogata, Masato, ed. "Kyō Yūzen ni Kansuru Chōsa”, [A Survey on Kyō Yūzen], Kyoto: Kyoto Chamber of Commerce and Industry, 1940.

Kyoto Kōgei Senshō Kyōdō Kumiai, ed. "Kyō Tegaki Yūzen, Sen-shō - Dentō no Waza, Kyō no Kimono" [Kyoto Hand-Painted Yūzen, Sen-shō Traditional Techniques, Kyoto Kimono]. Kyoto: Kyoto Kōgei Senshō Kyōdō Kumiai, (n.d.).

Kyoto Marubeni, Kabushikigaisha Senshoku Bijutu Kenkyukai, ed. Biten: Shōwa no Ayumi [Biten: Showa History]. Kyoto: Kyoto Marubeni Kabushikigaisha Senshoku Bijutu Kenkyūkai, 1989.

Marubeni Shōten Kyoto Shiten ed. Dai Nijukkai Senshoku Bijutsu Tenrankai [20th Textile Art Exhibition Catalog]. Kyoto: Unsodo, 1936.

Murakami, Bunka. Kindai Yūzen-Shi [History of Modern Yūzen]. Kyoto: Unsodo, 1927.

Nihon Kogeikai, ed. Nihon Dentō Kogeiten Zuroku, Dai San Kai. Kyoto: Unsodo, 1956.

Okada, Yuzuru and Nakamura, Katsuma, ed. Nakamura Katsuma: yūzen. Tabata Kihachi: yūzen. Ueno Tameji: yūzen. Yamada Eiichi: Yūzen Yōjinori. Ningen Kokuhō Series 12. Tokyo: Kodansha, 1981.

Okamoto, Keiko. "The Modern Development of Kyoto Textiles for the Kimono." In The Social Fabric:

Deep Local to Pan Global; Proceedings of the Textile Society of America 16th Biennial

Symposium, n.p. Vancouver: Textile Society of America, 2018.

https://doi.org/10.32873/unl.dc.tsasp.0042

Todate, Kazuko. Nakamura Katsuma to Tokyo Yüzen no Keifu, [Nakamura Katsuma and Tokyo Yūzen: The Development of the Individual Yūzen Artist]. Kyoto: Senshoku to Seikatsusha, 2007.

Ueno Kenkyukai. Seijuen, 8 vols. Kyoto: Unsodo, 1932-1933.

Ueno Seiji, Indo Senshoku no Tabi, Tsugita. [Ueno Seiji, Textile Trip to India, Tsugita]. In Some to Ori, May. 121, 1978.

Ueno, Seiko. Hana no Kake. vol. 2, 3, 4, 5. Kyoto: Honda Ichijiro, 1900.

-----. Shiki Moyau, vol.2. Kyoto: Honda Unkindo, 1901.

Ueno, Tameji. Chikusa. Kyoto: Unsodo, 1935.

-----. Yojō Hiinakata. Kyoto: Unsodo, 1933-1937.

-----. Tsurezuregusa. Kyoto: Unsodo, 1936.

-----. Yūzen Monogatari: Kyō-Kaga no Bi [A Story of Yūzen: The Beauty of Kyō-Kaga.] Modern Design of Japan. Kyoto: Unsodo, 2007.

Utsukushii Kimono [Beautiful Kimono]. Tokyo: Fujin Gaho-sha, 1987, Vol. 142.

Utsukushii Kimono [Beautiful Kimono]. Tokyo: Fujin Gaho-sha, 1989, Vol. 150.

Utsukushii Kimono [Beautiful Kimono]. Tokyo: Hachette Fujin Gaho-sha, 2004. Vol. 210.

Yamanobe, Tomoyuki. "Kyoto no Kindai Senshoku" [Modern Textiles in Kyoto]. In Kyoto no Kindai Senshoku, edited by Muromachi Senshoku Emaki Kaisai Iinkai, and Senshoku-ten Bukai, 9-16, Kyoto: Kyoto Orimono Oroshi Shōgyō Kumiai, 1994. 